\title{
Editorial: Screening the Skin: Issues of Race and Nation in Screendance
}

Melissa Blanco Borelli, Royal Holloway University of London

Raquel Monroe, Columbia College, Chicago

Keywords: race, whiteness, screendance, curation, film analysis

Sweat glistens, and drips from her long, sinewy, brown limbs. She quivers, vibrates, and shakes. The camera cuts from a close up of her trembling body to audience members searching for their seats. They sit and gaze at the dancer upstage right. Her staggered breath fills the quaint performance space. Dancer and choreographer Okwui Okpokwasili states that she convulses in this manner for thirty minutes to transition the audience into the intimate space of a brown girl trying to make sense of her adolescent sexuality in a world that attempts to deny her humanity. The documentary film Bronx Gothicnot only archives this Bessie Award winning solo performance of the same name, but also provides audiences access to Okpokwasili's reflection on the work, audience reactions, and Okpokwasili's intimate relationships with her family. Okpokwasili created Bronx Gothicas a live performance to capture the intimate lives of Black and Brown girls which are so often absent from popular media. Okpokwasili "want[ed] to make a space where there's a complicated and vulnerable experience around being in a Brown or Black girl's body, so why not put this in a film where it can live?"1 The documentary emerged from her desire and filmmaker Andrew Rossi's simple request to document the tour of the piece. Okpokwasili use of the screen as a space to hold and document the particularities of Black and Brown girlhood signifies a shift in the relationship between artists of color and the assumed heteronormative, white space of the screen. This assumption of whiteness and the screen is what our special issue interrogates.

Artists of color have a paradoxical relationship to the screen. From the dancing blackface minstrels of the nineteenth century to the contemporary insidious depiction of Muslim terrorists, white supremacist ideologies have deployed the screen as a weapon to maintain the oppressive order of enslavement and colonization endured by people of color. Unfortunately, the images of dancing people of color circulated by the film and television industries often portray us as promiscuous simpletons with an uncanny ability to move our bodies-as-commodities, but unable to intellectually engage with the world around us, care for ourselves or maintain functional, flourishing communities. While black and brown bodies dancing on screen are ubiquitous, their elegant vitality cannot be fully contained by it. As a result, when a black or brown

The International Journal of Screendance 9 (2018).

(C) 2018 Borelli and Monroe. This article is published under a Creative Commons Attribution 4.0 International 
subject controls their power of representation different images and imaginaries emerge. Okpokwasili's Bronx Gothicattests to how artists of color continue to find ways to strategically employ dance on the screen as a mechanism to engage broader audiences in discussions about racialized identity, pleasure, politics, and aesthetics. That Bronx Gothic traverses across the specifics of screendance festivals into independent film houses, black, and documentary film festivals illuminates the desire for films by and about people of color. ${ }^{2}$ Further, Okpokwasili's ethereal duet with dancer Storyboard Pete in rapper Jay-Z's acclaimed music video "4:44" exemplifies how artists of color blur the lines between the popular and the experimental to influence the socio-political discourses affecting their communities.

As we write these opening remarks to our guest edited issue on screendance and race, Janelle Monae has recently released Dirty Computer - An Emotion Picture. Its tagline states it is a narrative film with an accompanying music album. But Monae's persistent jabs at the vectors of oppression she navigates as black, femme, and pansexual successfully come together in this Afrofuturist utopian screen fantasy she helms. Dirty Computer celebrates love, black excellence, sex-positivity, otherness and queerness. While couched within the neoliberal discourses of empowerment and celebrations of selfhood, that Monae wields creative control attests to the extensive contributions black women make to global popular culture.

Another recent contribution to screendance is the video for Childish Gambino's (Donald Glover) "This is America." Rwandan choreographer, Sherri Silver, helped contribute to the stylistic novelty of the video by fusing a variety of African diaspora social dances. The almost incongruous pairing of these lively dances with the graphic gun violence depicted in the video aids to its popularity (as of this writing it has had over 234 million views on YouTube). A shirtless Gambino sings and dances, accompanied by Black children in school uniforms who shake, shimmy and jump behind him. Gambino bugs his eyes from time to time, dances the American Nae Nae, the South African Gwara Gwara, isolates his bare chest, before pulling out a gun to execute a hooded black man playing guitar, and later massacres a black Baptist Gospel choir. Gambino's performance interpellates America's history of racialized violence, minstrelsy, and religious hypocrisy. He makes it satirically uncomfortable; painfully so. While violence and destruction continually happen in the background, we are "entertained" by black performance. Yet this entertainment is anything but. It confronts us with our own sinister complacency and varying levels of complicitness in the systemic racist violence, it asks for an accountability for the violence of the gaze, the one couched in white supremacist logics, that has historically cemented how we look, and more importantly, how we care or dismiss those we look at.

Both videos were released weeks after the live stream of Beyoncé's performance at the Coachella Music Festival in April 2018. Accompanied by a New Orleans style big brass band, step teams, and dancers, Queen Bey's performance harkened the music and 
dance traditions of America's Historically Black Colleges and Universities (HBCUs), which led pop culture bloggers and journalists to proclaim her performance as not only the "blackest performance" ever, but also the best performance of 2018 thus far. All three of these black popular screendance contributions demonstrate how YouTube and Vevo emerge as the dominant platforms for the circulation of dancing black and brown bodies on screen. We have yet to see such a consistent circulation outside of the popular screen platforms that social media, live streaming and viral videos offer. In contrast to the popular screen, the popularity of Rossi's documentary of Okpokwasili's Bronx Gothic evidences the paucity of bodies of color in screendance festivals, thus the need to increase efforts to diversify the field of screendance at both the critical and creative levels.

The essays, provocations, and reviews in this volume document the efforts and artistry of people of color making dances for the screen in all of its manifestations. We have tried to look at global circulations of screendance and intersections among race, class, nation, gender and sexuality. We turn to a wide assortment of scholars, scholar-practitioners, and curator-practitioners to help us assess a screendance field of color.

Stephanie Batiste begins our collection with an evocative, critically engaged rendering of Kyle Abraham and Carrie Schneider's screen collaborations / am Sold and Blood on the Leaves. Not only do these films function as testaments to queer black love and care, but as Batiste argues, they complicate the ways racialised/racist history coupled with possibilities of intimacy offer new ways for black social transformation.

Elena Benthaus invites us to experience a different kind of hearing and witnessing through her analysis of black girlhood in the film The Fits. Benthaus' eloquent argument details how the film as a dance film affectively enfolds its spectator in a variety of orienting or disorienting ways depending on one's familiarity with the aesthetic, corporeal, rhythmic and aural registers it uses. Ultimately, Benthaus demonstrates the interconnectedness between movement and music in black aesthetics.

Alexandra Harlig adroitly takes on the racialized economy of popular dance and addresses how "the possibility of self-controlled outlets changes the reception for commercial mediation of popular dance by communities of practice." She examines the different ways advertisers, amateurs, entrepreneurs, music industry performers, and other professionals use, innovate, circulate, appropriate, and monetize dance on and through social media platforms. Harlig navigates through this complex web of popular screendance identifying and articulating points of critical entry for further engagement with this rich field.

Laura Robinson steers us towards screendance competitions in British television where the virtuosic feats of black male dance crews reify constructions of hyper-blackness and reduce the dancers' performances to mere spectacle. Robinson's insightful analysis 
challenges the tendency to devalue spectacle because of its intrinsic relationship to commodity culture. Instead, she skillfully theorizes that the spectacular performances by the black male dancers invoke "themes of aspiration and transformation that enable a re-valuing of televised spectacle."

Addie Tsai's rich foray into a genealogy of the trope of the white man who can't dance moves us through Patrick Swayze, the NFL, Magic Mike, and Eddie Murphy to elucidate how a simple choreographed sequence in Dirty Dancing and its subsequent iterations facilitate inquiries into (white) hegemonic masculinity, heteronormativity, spectacle and black masculinity.

Jingqiu Guan's discerning read of how the dance film An African Walks in the Land of China depicts the relationship between immigrant Africans and working class Chinese. Her article moves us from the popular screen to international screendance. Guan engages performance analysis with theories of transnationalism to offer an illuminating critique of how the film successfully explores the economic development of "ChinAfrica," yet fails to subvert the colonial gaze from African and Chinese bodies.

Cara Hagan carefully tracks the historical development of screendance to elucidate how its roots in concert dance, film festivals and museum culture situate it within the whiteness of these genres. Hagan's refreshing analysis provides insight into the efforts made by curators of screendance festivals to diversify their offerings. Still, she challenges the industry to investigate funding sources and production requirements that inhibit diversity.

In his provocation, Marcus White responds to Hagan's request for the screendance industry to reflect the diversity of dance and dancemakers. He articulates how his and Carlos Funn's creation of Moving 24fps provides a platform for artist of color to collaborate and create screendances within a 24 hour time period. White notes however, that while Moving $24 \mathrm{fps}$ succeeds at producing films by and about people of color, the primary consumers of screendance remain white. He leaves us to ponder, how do we cultivate diverse audiences for screendance?

Mark Broomfield strategically confronts the stranglehold cis-gendered heterosexual men have on masculinity, in his documentary film Danced Out. Broomfield contends that the film centers the experience of queer dancers of color systematically excluded from the discourse on masculinity. Broomfield looks to gay male dancers of color who are intimately familiar with performances of masculinity on and off the stage.

Michael Sakamoto's critical interview with dancer Angella Betina Carlos reflects on their collaborative film Abbey. The film evidences the isolation immigrants of color experience in predominantly white U.S university dance programs. The interview grapples with the dynamic relationship between Sakamoto as filmmaker and Carlos as dancer/ choreographer. Ultimately, the interview reveals how their collective but 
different experiences as "gendered subalterns" creates a space for Carlos to explore her transnational Asian identity through her dancing body.

We close our issue with Adriadne Mikou's review of the Italian film // Mio Grido. Mikou celebrates the extent to which the choreography and film editing humanizes the racially and ethnically diverse men incarcerated in the Rovigo Penitentiary.

The contributions in this volume provide a glimpse into the possibilities of what a more inclusive screendance field might look like. We are hopeful that creative and critical engagements by and about communities/artists of color (and all of their intersectional alliances) will continue to facilitate more nuanced discussions about identity, citizenship, affect and community particularly at such a vulnerable moment in our history. Diversity, while necessary, is often co-opted by neoliberal ideologies of a neat multiculturalism where differences are underplayed in service to greater discourses of productivity and monetization. We urge scholars, curators, and scholar-artistpractitioners of screendance to engage with diversity, not as another zeitgeist term, but as an invitation to broaden the field of artistic production. A new visual terrain can surely emerge, one that expands our ethical consideration of (un)familiar others and will help shift our fields of vision beyond what is readily comfortable and recognizable.

\section{Biographies}

Melissa Blanco Borelli is Senior Lecturer in Dance in the Department of Drama, Theatre \& Dance at Royal Holloway, University of London in their. Her research interests are always interdisciplinary: critical race theory, black and Latinx cultural production, media, film, popular culture, feminist historiography, performance ethnography and performative writing. She is author of She is Cuba: A Genealogy of the Mulata Body (recipient of the de la Torre Bueno Prize for Best Book in Dance Studies, 2016, Dance Studies Association), and the editor of The Oxford Handbook of Dance and the Popular Screen. Other scholarship has appeared in edited collections Black Performance Theory, The Oxford Handbook of Screendance, Zizek and Performance, and the journals Women and Performance, Brolga, International Journal of Performance and Digital Media, and International Journal of Screendance. She is the incoming Editor for Conversations Across the Field of Dance Studies.

\section{Email: Melissa.Blanco@rhul.ac.uk}

Raquel Monroe is an Associate Professor in Dance at Columbia College Chicago. As an interdisciplinary performance scholar and artist her research interests include black social dance, black feminisms, and popular culture. Monroe's scholarship appears in the 
Journal of Pan-African Studies, the edited volumes Queer Dance, solo/black/woman: Performing Black Feminisms, and The Oxford Handbook: Dance and the Popular Screen. She is completing a manuscript that investigates how black feminist politics emerge through the dancing bodies of black female cultural producers in popular culture.

Email: rmonroe@colum.edu

\section{Notes}

${ }^{1}$ Color Lines. "Four Questions" https://www.colorlines.com/articles/4-questions-bronxgothic-creator-and-star-okwui-okpokwasili accessed 31 May 2018.

${ }^{2}$ Bronx Gothic has been screened at:

Miami Light Project, http://www.miamilightproject.com/screendance_miami;

Chicago Museum of Contemporary Art, https://mcachicago.org/Calendar/2018/04/Screening-Andrew-Rossi-And-Okwui-

Okpokwasili-Bronx-Gothic;

Barnard College, https://barnard.edu/events/bronx-gothic;

Project Row Houses, https://projectrowhouses.org/calendar/bronx-gothic-screeningperforming-the-neighborhood;

Film Forum, http://www.blouinartinfo.com/news/story/2304540/bronx-gothic-at-filmforum-new-york 